\title{
Cultural capital and the density of organised interests lobbying the European Parliament
}

\section{Brendan J. Carroll \& Anne Rasmussen}

To cite this article: Brendan J. Carroll \& Anne Rasmussen (2017) Cultural capital and the density of organised interests lobbying the European Parliament, West European Politics, 40:5, 1132-1152, DOI: $10.1080 / 01402382.2017 .1303243$

To link to this article: https://doi.org/10.1080/01402382.2017.1303243

(c) 2017 The Author(s). Published by Informa
UK Limited, trading as Taylor \& Francis
Group

Submit your article to this journal $匚$

Џلll Article views: 827

Q View related articles $\sqsubset$

View Crossmark data \lceil

Citing articles: 4 View citing articles ๘ 


\title{
Cultural capital and the density of organised interests lobbying the European Parliament
}

\author{
Brendan J. Carroll ${ }^{\mathrm{a}}$ and Anne Rasmussen ${ }^{\mathrm{a}, \mathrm{b}}$ \\ anstitute of Public Administration, Leiden University, The Hague, The Netherlands; ${ }^{\text {b Department }}$ \\ of Political Science, University of Copenhagen, Denmark
}

\begin{abstract}
Drawing on a new dataset the article investigates a case study of the population of interest representatives lobbying the European Parliament. It examines the role of economic and cultural resources to account for the representation of organised interests from different EU member states. It adds to the existing literature on the density of organised interests by showing that in addition to economic resources, cultural capital plays a significant role in stimulating the activity of organised interests. Whether countries have a high number of organised interests in the parliament's interest group community depends on both whether they are economically prosperous and how large a share of their citizens participate in associational life. In addition, the findings demonstrate how the ranking of countries in the population of organised interests lobbying the parliament depends on the benchmark used to measure density.
\end{abstract}

KEYWORDS Interest groups; European Parliament; social capital; lobbying; multilevel governance

During the frequent waves of negotiations about its institutional structure, the EU has often revealed an inherent tension in the balance of power between representatives from the member states in its formal bodies. As an example, the balance of seats between the member states has been a complex issue in the European Parliament (EP) (Corbett et al. 2007). ${ }^{1}$ In September 2007, when members of the European Parliament (MEPs) debated their own proposal for the redistribution of its seats, one of the two co-rapporteurs of the parliament on the matter, Mr. Lamassoure, emphasised how 'reason and logic should prevail over passion and national interest ${ }^{2}$ on an issue which he later characterised as 'a hot potato.' The question of how the EP should be composed is important in light of the substantial increase in its powers over the last decades. The EP has gone from being a consultative body with limited powers to acting as a co-legislator in the vast share of EU legislative areas (Burns et al. 2013; Lehmann 2009).

CONTACT Brendan J.Carroll b.j.carroll@fgga.leidenuniv.nl

(c) 2017 The Author(s). Published by Informa UK Limited, trading as Taylor \& Francis Group.

This is an Open Access article distributed under the terms of the Creative Commons Attribution-NonCommercialNoDerivatives License (http://creativecommons.org/licenses/by-nc-nd/4.0/), which permits non-commercial re-use, distribution, and reproduction in any medium, provided the original work is properly cited, and is not altered, transformed, or built upon in any way. 
The expansion of EP power has made it a more attractive venue for lobbyists and has given rise to increased attention from the interest group community (e.g. Kohler-Koch 1997; Marshall 2010; Rasmussen 2015; Wessels 1999). The relative emphasis on lobbying the EP as opposed to other venues has risen. Studies of companies have shown that these devote an increasing share of their resources towards lobbying the EP (Coen 1997). Of the 8462 actors listed in the EU Transparency Register in April 2015, 2044 held one or more passes to the EP. ${ }^{4}$ This is a high share given that many of the organised interests listed in the Transparency Register are unlikely to have a permanent physical presence in Brussels.

Organised interests lobbying the EP exist in many forms including membership associations, firms, think tanks and national institutions (Baroni et al. 2014). There are various ways of classifying the interests they represent. Some actors can be grouped according to functional, substantive interests (such as producers, consumers or labour) whereas for other types of actors such a classification is harder to make. At the same time, a substantial share of the organised interests present in Brussels have their roots in different member states (Eising et al. 2017; Rasmussen and Gross 2015; Wonka et al. 2010). Yet, to date, research on the population density of organised interests in the EU has focused on explaining variation in the number of organised interests between different policy issues and areas (Broscheid and Coen 2007; Coen and Katsaitis 2013; Rasmussen et al. 2014) as well as between economic and social sectors of group activity (Berkhout et al. 2015; Messer et al. 2011) rather than between countries.

Our analysis makes two important contributions: we perform the first systematic study of the population density of interest groups from different member states lobbying the EP. We pay attention to their absolute number as well as to relative measures of the density of these organised interests. Regarding the latter, we place the national interest organisations in relation to different country-specific benchmarks (see also Gray and Lowery 2000) such as the size of the national economy, the size of the national population and the country's number of seats in the EP. These benchmarks help us to link the examination of interest group density to the wider study of descriptive representation in the EP. ${ }^{5}$ Second, we add to existing work on the density of organised interests in the US and the EU (for a recent review, see Berkhout et al. 2015) by considering not only economic but also cultural resources as a source of the density of an interest group population. Relying on the social capital literature (see e.g. Andrews 2011; Boix and Posner 1998; Putnam 1993; Tavits 2006) we develop our argument that cultural resources also serve as important push factors for the mobilisation of organised interests vis-à-vis the EP. We hypothesise that a strong national associational culture stimulates the volume of national, organised interests active in the EP. Our analysis is based on a new dataset of the population of organised interests registered to lobby the EP between 2005 and 2009. The data was coded in the European-wide INTEREURO project (Beyers et al. 2014). 
It is essential to understand how well represented national interest groups are in the EU system in an institution such as the EP, which is a co-legislator in the vast share of the policies dealt with by the EU. Moreover, it is widely recognised that organised interests play a particularly prominent role in the EU. In the EU's political system, political parties do not play the same role as in the member states when it comes to transmitting public views to decision-makers (Lindberg et al. 2008). Instead there is a high emphasis on securing legitimacy through the involvement of civil society whose participation is actively encouraged and financially supported by the EU institutions. ${ }^{6}$ Clearly, organised interests need to respond to a range of different principals apart from their national constituency as a whole: Organised interests typically represent different substantive interests irrespective of which country they come from. At the same time, territorial interests are also important in the complex EU construction, which is still far from being an actual state. Rather it forms a political system in which national divisions between countries with different attitudes towards European integration play a role in many political discussions alongside other types of conflicts (Marks and Steenbergen 2004).

Our findings underline the value of considering the number of organised interests in relation to different benchmarks. These help us to obtain a more nuanced picture of the density of different national populations of organised interests lobbying the EP. Our findings show important similarities between various countries in the relative density of their organised interests even though the choice of benchmark also affects the ranking of a given country. Most importantly, the old member states have a significantly higher interest group density per seat in the EP than younger member states. Moreover, in line with our expectations we find evidence that not only economic but also cultural resources play a role in accounting for the number of national organised interests lobbying the EP. Both countries with a large economy as well as those with a large share of the population active in voluntary associations have a high number of interest representatives lobbying the EP. These findings have important implications for understanding national representation in EU lobbying as well as for future theorising about the density of organised interests.

\section{Lobbying the European Parliament}

As already mentioned, the strengthened role of the EP and its increased relevance as a venue for organised interests active in EU lobbying has not gone unnoticed in the literature (Lehmann 2009). Studies of EP lobbying have for example examined the access of organised interests to the EP and other institutions (see e.g. Bouwen 2004; Dür and Mateo 2012; Eising 2007), the strategies of organised interests with respect to who to lobby in the EP (e.g. Marshall 2010, 2015) as well as the lobbying success of organised interest groups in the EP (e.g. Baroni 2014; Rasmussen 2015). Our aim is to explain cross-national variation 
in the number of organised interests lobbying the EP. Our focus is thus not on explaining which elements at the level of individual, national groups determine whether they decide to actively lobby the EP (see e.g. Dür and Mateo 2012; Eising 2007) but in understanding country-level differences in the representation of organised interests at a higher level of aggregation.

Representation is a complex phenomenon involving many different dimensions, such as: are elected politicians representative in terms of descriptive characteristics (e.g. race, gender)? Do they enact policies in line with the substantive interests of their constituencies (see Pitkin 1967)? We are interested in the descriptive representation of different geographical areas, or what has been referred as 'territorial representation' in work comparing the opinion of voters and MEPs in different EU countries (Marsh and Wessels 1997). In the EU literature on interest representation, a distinction has sometimes been made between studies examining 'territorial interest representation' of EU subnational entities (regions and localities) and those examining 'functional interest representation' of different substantive interests such as business versus labour (Knodt 2011). These different forms of interest representation have been portrayed as occurring in different types of arenas even if there is not necessarily a strong cleavage between functional and territorial interest representation in practice. In fact, many commonalities can be found in the strategies of regions and interest groups (Knodt 2011; see also Tatham 2017). Therefore, we do not depart from the assumption that interest organisations always represent a specific type of interest or contribute to a specific form of representation, be it 'territorial', 'functional' or maybe sometimes even 'party political'. Instead, organised interests may represent and align different types of interests in practice.

Understanding representation of interest representatives from the different member states in EU institutions such as the European Parliament is important in the EU which - despite sharing many attributes of a political system - is not a state (Hix and Hoyland 2011). As a result of variation in both the level of regulation and regulatory traditions across the EU member states, policy negotiations in Brussels often need to find compromises between different political parties and different national interests. In such negotiations, interest organisations not only speak on behalf of specific substantive interests but may also represent distinct national approaches to tackling a given policy issue. Therefore, organised interests of the same type - such as trade unions or business groups - from different member states do not always represent a unified front on a given issue. Similarly, MEPs from a given party group within the EP may sometimes be divided according to their national affiliation. This emphasises the need to consider how actors from different EU member states are represented in the EU, not only in the formal EU bodies but also in the population of interest representatives. Existing research makes it clear that alongside European associations, national associations continue mobilising and getting access to the EP (e.g. Bouwen 2004; Eising 2007). 


\section{Explaining variation in national groups}

We share the interest of scholars studying the density of interest groups (Gray and Lowery 2000) in modelling differences in the number of organised interests across 'aggregate units' (in our case: countries). However, we expand the focus of the existing cross-national studies. These have focused on explaining variation in the number of trade and business associations (Bischoff 2003; Coates et al. 2007) or that of interest representatives that attend the ministerial conferences of the WTO (Hanegraaff et al. 2015). The number of groups present in political venues is not only important in its own right but also because it may impact on other aspects of interest representation, such as the strategies and potential lobbying success of groups as well as the performance of the political system as a whole (Berkhout et al. 2015; Messer et al. 2011). ${ }^{7}$ Similar to work done by interest group population ecologists on the US states (Gray and Lowery 2000), we focus on the structural determinants of the activity of organised interests from different territorial entities. Our explicit focus is on how the supply of resources (or the 'area') available to groups affects the number of groups lobbying the EP. We also control for demand-side factors that might create an incentive for them to mobilise. According to Berkhout et al. (2015: 464), the EU system may be a least likely case for finding an effect of supply-side explanations given the "long causal chain between "supply" factors and the actual lobbying venue, whereas considerable support for demand-side effects were found in early work in this context (see e.g. Broscheid and Coen 2003). Moreover, we add to existing work on population ecology in interest group research by considering not only economic but also cultural resources as a factor that might affect the capacity of national groups to lobby the EP.

To begin with, the literature on organised interests contains no lack of accounts of how economic resources affect the mobilisation of individual groups. The interest group community in both the EU and elsewhere has often been accused of being 'biased' towards resourceful groups (Rasmussen and Carroll 2014; Schattschneider 1960; Schlozman 1984). Access to resources should make it easier for national interest representatives to expand the range of their lobbying activities from the national to the supranational level. Mobilising at the EU level requires resources to monitor policy-making, to design and implement strategies and to forge alliances with other stakeholders (for a similar argument related to transnational advocacy, see Hanegraaff et al. 2015). In work on the mobilisation of subnational governments in Brussels, Marks et al. (1996) speak of a 'resource push': a greater amount of financial resources facilitates EU-level activity.

In a similar way, explanations of the density of organised interests by interest group population ecologists attach high emphasis to the importance of economic factors when it comes to explaining the number of groups. Just as biological species depend on resources for their survival, the number of groups is 
expected to be constrained by the economic resources available in their environment (Berkhout et al. 2015; Gray and Lowery 2000). According to population ecology, increases in organisational constituents will result in larger populations because more constituents should make it possible for organisations to represent niches of interests that are narrower and more specific. Moreover, the number of interest groups is not only affected by the number of potential constituents (e.g. the number of firms in the case of a business association) but also by the wealth of those constituents given that better-endowed interests are more likely to mobilise in the first place (Berkhout et al. 2015).

In line with such a logic, work on the density of national trade associations has found evidence that economic development stimulates a higher number of interest groups (Bischoff 2003; Coates et al. 2007). Economic development lowers the costs of group mobilisation through better transportation and information infrastructure, which makes it easier to both form and maintain organised interests (Bischoff 2003). It also increases the total number of interests in a society through labour specialisation, product differentiation and the growing choice of products and activities that consumers with additional income possess. Our expectation is therefore that the economic resources of a country can help stimulate the activity of organised interests. However, importantly, we do not expect the relationship between economic resources and interest group density to be linear. As argued by population ecologists, decreasing returns to scale will mean that the marginal utility of additional groups will start declining at some point as more resources become available (Berkhout et al. 2015). Our first hypothesis is therefore that the number of organised interests from a country lobbying the European Parliament increases with its amount of economic resources but at a declining rate.

Yet, apart from economic resources, historical legacies and cultural traditions might also be important among the supply-side factors that stimulate the number of organised interests from a country. Putnam (1993) has for example argued that a country's legacy with respect to associational engagement may have an impact on the status of its current civil society (see also Bailer et al. 2013). Such associational activity has often been regarded as an important component of the concept of 'social capital', which is a term used to evaluate the quality of the social environment among people (Coleman 1990: 304; Putnam 1995). The idea is that citizens acquire social capital through their interactions and networks with others. This social capital may help them achieve their goals more effectively and have a positive impact on societal governance more generally. Even if the usage of the concept of social capital in the recent literature has not escaped criticism (e.g. Jackman and Miller 1998), several studies have provided evidence of a link between social capital and the effectiveness of public governance (e.g. Andrews 2011; Cusack 1999; Putnam 1993). Rather than referring to the general concept of social capital, which aggregates many different sub-dimensions (e.g. Putnam 2000), we look directly at support for voluntary associations. 
Such support and engagement in civil society organisations can serve as a foundation for the maintenance of a strong lobbying presence not only at the national but also the supranational level. It may for example increase the level of political sophistication within a given society, which will in turn help overcome potential collective action problems and ensure that citizen demands are articulated (Boix and Posner 1998; Putnam 1993). According to Putnam (1993: 183), 'Where norms and networks of civic engagement are lacking, the outlook for collective action appears bleak'. A higher stock of associational capital makes it more likely that collective action takes place resulting in a higher degree of policy activism by which citizens and organised interests aim to monitor and influence government (Andrews 2011; Tavits 2006). The idea is that participation in voluntary association stimulates a learning process in which national actors become more exposed to information and the benefits of actively engaging in policy activism such as EP lobbying. In a study on the mobilisation of subnational governments in Brussels, Marks et al. use a similar line of reasoning. They argue 'that the skills and habit developed within a strong associational culture may spill over into public life' (Marks et al. 1996: 169) and exert a positive influence on the likelihood of having regional representation in Brussels. Accordingly, the regions with the strongest associational culture should be the ones most visible in the lobbying landscape. Even if their data requires them to test this argument via an indirect proxy (the share of the workforce in the industrial sector), they find considerable support for the idea. Following the argumentation above, our second hypothesis is that there is a positive relationship between the share of the public active in voluntary associations and the number of organised interests from a country lobbying the European Parliament.

\section{Data and variables}

To examine the density of interest group representatives from different countries in the EP, we rely on a dataset collected for INTEREURO, an international research project examining multiple facets of interest group lobbying in the EU and its member states (Beyers et al. 2014). The population consists of all organisations that held a 'doorpass' to access the EP building for any period of time between 2005 and 2009. Given our focus on national groups lobbying the $\mathrm{EP}$, using a register for this institution only is key for us. The data for a five-year period allows us also to control for short-term fluctuations in the representation of organised interests from different countries. Importantly, this period was not marked by radical changes in the use of the register itself in comparison to the EU's Transparency Register. The latter has experienced several changes in the rules guiding registration and witnessed a steep increase in the number of registrants ever since its introduction in 2011. Relying on the INTEREURO coded dataset also gives us the distinct advantage that we do not have to rely on 
self-reported information about the groups that has been the subject of criticism (ALTER-EU 2012). Moreover, our INTEREURO doorpass data enable us to single out groups by using the coded information about the scope of interest that they represent. ${ }^{8}$

From our dataset we select all organised interests that are headquartered in an EU member state and represent national or subnational interests. To create our dependent variable, we aggregate numbers of groups across the entire five-year period to smooth out marginal differences over time and to construct density measures based on the largest possible number of organised interests. The number of groups varies only marginally over time as our data are for a relatively short time period. The main variation is thus cross-national and not time-varying, such that cross-sectional variation is the main focus of our explanation. ${ }^{9}$

In total, 693 business associations, firms, citizen groups, labour and professional associations, institutions, national authorities and other actors from the member states are present in the registry for this period. Rather than restricting the term 'organised interest' to membership associations, we are thus employing a broader, behavioural definition, which classifies actors 'based on their observable, policy related activities' (Baroni et al. 2014: 142; see also Beyers et al. 2008). Among these groups, 112 are located in Belgium, whose capital Brussels hosts not only central government authorities but also the EP itself, giving its organised interests a unique advantage in terms of access to this institution. Because of this exceptionalism, we exclude Belgium from the analyses that follow.

The first part of our empirical analysis explores national differences in density. Rather than only considering the raw number of groups, we also examine relative density measures, thus placing the number of groups in relation to different benchmarks. Already when Gray and Lowery published their seminal book they emphasised that:

While a raw number of interest organizations provides a starting point for measuring interest population density, it is not obvious that by itself it is an adequate indicator. Density is a relational concept ... Therefore, numbers of organizations must be compared to some frame of reference to give the indicator meaning in terms of the underlying concept of density. (Gray and Lowery 2000: 86)

We therefore compare different density measures such as: (a) absolute density (i.e. the number of groups per country); (2) GDP per organised interest; (3) citizens per organised interest; and (4) EP seats per organised interest. This helps us to give more nuanced answers to the broader question of representation to which our work relates.

The second part of the analysis aims at explaining variation in density between countries. Our main goal is to examine the explanatory power of cultural versus economic resources. Following Gray and Lowery (2000) we model the absolute number of organised interests in this part of our article. According to Gray and Lowery, such a strategy is advantageous given that relative density measures (such as citizens per organised interest) are not 
natural entities that act or are acted on directly. They are products or artifacts of what happens to numbers of interest organizations in relation to something else ... Therefore, when our focus shifts to explanation ... attention will be given exclusively to interest organization numbers. (Gray and Lowery 2000: 107-8)

We model the differences in density by regressing the total count of organised interests on two main independent variables that capture economic and cultural resources, respectively, and controlling for alternative explanations. With the exception of our measure of cultural resources (described below), we average the independent variables over the 2005-2009 period.

For economic resources, we measure the size of a country's economy by its GDP (obtained from Eurostat). Because we do not expect a linear relationship between economic size and density but instead one that reflects diminishing marginal returns to economic size (that is, the effect of wealth on density remains positive but diminishes in magnitude with wealth), we take the logarithm of this variable.

For cultural resources we use a measure of associational membership adapted from Norris (2003). We construct the measure based on a question included irregularly in Eurobarometer surveys. Respondents are asked to select from a list of 14 types of voluntary membership organisations ${ }^{10}$ (and one residual choice for membership organisations not included in the 14) the ones to which they belong. We then take the share of respondents who indicate membership in any one category of voluntary organisations. Using survey weights, we finally determine the share of citizens in each member state that belong to such organisations. Within our time period from 2005 to 2009, only Eurobarometer 66.3 (fieldwork conducted in 2006) includes the question, so we construct our measure from this survey alone. Among the 26 member states used in the analysis, the average national share of individuals participating in voluntary organisations is $31 \%$ with a low of $10 \%$ (Bulgaria) and a high of $60 \%$ (Austria). ${ }^{11}$

As mentioned, the number of national groups may not only be a question of the capacity but also the incentive of groups from a given country to seek rents from mobilising. Hence, organised interests from some countries may have a higher incentive to be active in the European Parliament than others. Therefore, we control for two additional factors that represent incentives for organised interests to mobilise at the EP. The first represents EU expenditures in each of the member states and measures the direct transfers to each country (in billions of euros), obtained from the website of the Directorate-General for Budget. The amount of EU fiscal transfers such as transfers of structural funds or agricultural subsidies to different member states varies so that some are greater beneficiaries of EU funds than others. This might provide interest groups from these countries with a greater incentive to maintain a strong presence in Brussels. The second reflects a country's reliance on trade within the EU and outside it. Groups from countries with high trade integration may be more 'energised' to get involved in lobbying the EU institutions since the 
EU regulatory environment ultimately affects them more (Rasmussen and Alexandrova 2012) (for a similar argument, see also Broscheid and Coen 2007; Cram 1998; Richardson and Mazey 2015). The internal market policies of the EU will be likely to draw national, organised interests from countries that benefit from trade within the EU. EU customs and competition policies will provide incentives for groups to mobilise from countries that benefit from external trade. Hence we measure trade reliance as the total value of imports and exports both with member states and with non-member states standardised by a country's GDP.

\section{Density of national, organised interests}

Table 1 shows cross-national differences in the density of organised interests from the EP doorpass registry using four alternative measures. The first is a simple count of the number of organised interests per country, and the table ranks the countries according to this measure (which will be the dependent variable in the next section). Germany has the most organised interests in the

Table 1. Interest groups in the European Parliament registry per country.

\begin{tabular}{|c|c|c|c|c|c|c|c|c|}
\hline Country & Count & Rank & $\begin{array}{c}\text { GDP/group } \\
\text { (euro } \\
\text { millions) }\end{array}$ & Rank & $\begin{array}{l}\text { Population/ } \\
\text { group } \\
\text { (thousands) }\end{array}$ & Rank & $\begin{array}{l}\text { EP seats/ } \\
\text { group }\end{array}$ & Rank \\
\hline Germany & 148 & 1 & 3991 & 8 & 556 & 9 & 0.67 & 3 \\
\hline Belgium & 112 & 2 & 734 & 1 & 95 & 1 & 0.21 & 1 \\
\hline France & 95 & 3 & 4854 & 15 & 669 & 12 & 0.81 & 4 \\
\hline Italy & 89 & 4 & 4258 & 10 & 665 & 11 & 0.86 & 5 \\
\hline $\begin{array}{l}\text { United } \\
\text { Kingdom }\end{array}$ & 74 & 5 & 6328 & 17 & 825 & 13 & 1.04 & 8 \\
\hline Netherlands & 43 & 6 & 3248 & 4 & 381 & 4 & 0.62 & 2 \\
\hline Spain & 36 & 7 & 7059 & 18 & 1244 & 15 & 1.48 & 10 \\
\hline Sweden & 19 & 8 & 4160 & 9 & 480 & 7 & 0.99 & 7 \\
\hline Austria & 18 & 9 & 3715 & 6 & 460 & 6 & 0.99 & 6 \\
\hline Denmark & 13 & 10 & 4278 & 11 & 420 & 5 & 1.06 & 9 \\
\hline Finland & 8 & 11 & 5381 & 16 & 660 & 10 & 1.73 & 11 \\
\hline Romania & 6 & 12 & 4669 & 14 & 3495 & 20 & 3.43 & 16 \\
\hline Hungary & 6 & 13 & 3958 & 7 & 1677 & 17 & 3.93 & 17 \\
\hline Ireland & 5 & 14 & 8727 & 19 & 866 & 14 & 2.56 & 13 \\
\hline Poland & 5 & 15 & 15,032 & 22 & 7628 & 22 & 10.64 & 21 \\
\hline Slovenia & 4 & 16 & 2088 & 3 & 503 & 8 & 1.75 & 12 \\
\hline Greece & 4 & 17 & 13,614 & 21 & 2793 & 19 & 5.90 & 18 \\
\hline Cyprus & 2 & 18 & 1954 & 2 & 381 & 3 & 3.00 & 14 \\
\hline Luxembourg & 2 & 19 & 4366 & 12 & 238 & 2 & 3.00 & 15 \\
\hline Estonia & 1 & 20 & 3542 & 5 & 1345 & 16 & 6.00 & 19 \\
\hline Latvia & 1 & 21 & 4567 & 13 & 2208 & 18 & 8.80 & 20 \\
\hline Slovakia & 1 & 22 & 13,261 & 20 & 5375 & 21 & 13.80 & 22 \\
\hline $\begin{array}{l}\text { Czech } \\
\text { Republic }\end{array}$ & 1 & 23 & 32,591 & 23 & 10,289 & 23 & 23.60 & 23 \\
\hline Bulgaria & 0 & & & & & & & \\
\hline Lithuania & 0 & & & & & & & \\
\hline Malta & 0 & & & & & & & \\
\hline Portugal & 0 & & & & & & & \\
\hline
\end{tabular}


register with a total of 148, while Bulgaria, Lithuania, Malta and Portugal had none during the examined period. The average number of organised interests per country is 22.4 (including Belgium it is 25.7), but most countries have fewer organised interests than the mean. The standard deviation of 37.7 is well above the mean, indicating a high variability.

The remaining columns of Table 1 show the density of organised interests in the EP in relation to three alternative benchmarks. The analysis is limited to those countries with at least one organised interest present. Beside each of these benchmarks is a ranking of each country in order of descending density. As the benchmarks all measure density inversely, the ranking is in ascending order of the values for each country.

We start by looking at GDP in relation to groups. Interest group research often emphasises how economic resources serve as an important basis of group activity (Schattschneider 1960; Schlozman and Tierney 1986). As a result, Gray and Lowery (2000) suggest using the size of the economy as a benchmark when assessing the number of groups. In order to do so, the column labelled GDP represents the gross domestic product in millions of euros per organised interest. It relies on the average GDP for each country across the five-year period for its construction. This measure of 'representational economic density' (Gray and Lowery 2000: 89) is an inverse measure of density as higher values indicate fewer groups relative to the size of a country's economy. It ranges from $€ 734$ million per group (Belgium) to $€ 32,591$ million per group (Czech Republic) with a means of $€ 6799$ and $€ 7075$ million per group with and without Belgium, respectively. Excluding Belgium, the densest countries with respect to this benchmark are a diverse set that includes countries with few organised interests (Cyprus and Slovenia) and one with a relatively high number of interest groups (the Netherlands).

The next benchmark we use is population. It measures the number of inhabitants (in thousands) in a country per organised interest (with population averaged across the five-year period). As with the previous measure it is an inverse density measure, with lower values indicating fewer inhabitants per group and hence higher density. Density using this benchmark ranges from 95,000 inhabitants per group for Belgium (the next highest is Luxembourg with 238,000 inhabitants per group) to over 10 million inhabitants per group present in the EP for the Czech Republic. This measure has an average of 1,881,000 inhabitants per group (or 1,962,000 inhabitants per group excluding Belgium). Countries that rank high on representational economic density tend to rank high on this measure as well, but there are some notable exceptions. Hungary drops from the seventh position in terms of GDP to the seventeenth position in terms of population; Estonia drops from the fifth to the sixteenth position and Luxembourg rises from the twelfth to the second position.

Finally, the last benchmark we use concerns representational political density and looks at the relationship between the number of organised interests 
from a country and its number of official MEPs in the European Parliament. The measure - calculated as the number of EP seats per organised interest - is also a measure of inverse density. On the one hand, the densest member states with respect to this benchmark are also the oldest member states: Belgium, the Netherlands, Germany, France and Italy are five of the six founding members of the European Economic Community. On the other hand, the least dense member states are all new member states (the Czech Republic, Slovakia, Poland, Latvia and Estonia occupy the highest ranks for this measure). The measure ranges from 0.2 (or 0.7 if Belgium is excluded) to $23.6 \mathrm{EP}$ seats per organised interest with an average of 4.2 and 4.4 with and without Belgium, respectively.

Thus although there are similarities in the ranking of countries when using these alternative benchmarks, the differences that remain suggest that assessments of the degree to which countries are represented by organised interests lobbying the EP depend to some extent on the chosen criterion of representation. Given the high correlation between GDP and population in EU countries, the difference in ranking between economic representation and representation by population is relatively small, with wealthy, smaller countries and relatively poorer but larger countries driving the differences observed. The departure from pure proportionality in EP seats (Delgado-Márquez et al. 2013) means that the ranking of EP seats per group differs from that of population per group. Remarkably, a pattern emerges for the former that follows the duration of EU membership.

\section{Variation in national numbers of organised interests}

As a next step, we now explore variation in the number of organised interests in the EP doorpass registry from 2005 to 2009 for $26 \mathrm{EU}$ countries (every member state during that period except Belgium). As our dependent variable

Table 2. Negative binomial regression explaining density.

\begin{tabular}{lcccc}
\hline & $(1)$ & $(2)$ & $(3)$ & $(4)$ \\
\hline Log of GDP & $1.061^{* * *}$ & & $1.064^{* * * *}$ & $1.038^{* * *}$ \\
Associational membership & $(0.084)$ & & $(0.045)$ & $(0.091)$ \\
& & $0.059^{* * *}$ & $0.020^{* * *}$ & $0.020^{* * *}$ \\
Direct transfers (euro billions) & & $(0.020)$ & $(0.004)$ & $(0.005)$ \\
& & & & 0.009 \\
Trade & & & & $(0.020)$ \\
& & & & 0.015 \\
Constant & $-23.973^{* * *}$ & 1.009 & $-24.789^{* * *}$ & $-24.069)$ \\
McFadden pseudo-R2 & $(2.138)$ & $(0.714)$ & $(1.195)$ & $(2.224)$ \\
Observations & 0.26 & 0.03 & 0.34 & 0.34 \\
Log Likelihood & 26 & 26 & 26 & 26 \\
$\Theta$ & -74.556 & -97.345 & -65.994 & -65.878 \\
& 6.284 & $0.451^{* * *}$ & 462.840 & 381.521 \\
Akaike Inf. Crit. & $(4.050)$ & $(0.122)$ & $(1756.730)$ & $(1184.140)$ \\
& 153.113 & 198.689 & 137.989 & 141.755 \\
\hline
\end{tabular}

Note: ${ }^{*} p<0.1 ;{ }^{* * *} p<0.05 ; " ; " * * 0<0.01$. 
is an overdispersed count of the number of organised interests, we estimate these models in Table 2 using negative binomial regressions. Because the raw coefficients of negative binomial regression models do not have a straightforward interpretation, we include the exponentiated coefficients in Table 3. The first model is a bivariate regression model of the number of organised interests on the logarithm of a country's GDP, the independent variable that represents a country's economic resources. The effect of this variable on density is as expected: a larger economy is associated with a higher density $(p<0.01)$. The

Table 3. Negative binomial regression explaining density (exponentiated coefficients).

\begin{tabular}{lcccc}
\hline & $(1)$ & $(2)$ & $(3)$ & $(4)$ \\
\hline Log of GDP & 2.890 & & 2.898 & 2.823 \\
& $(0.084)$ & & $(0.045)$ & $(0.091)$ \\
Associational membership & & 1.060 & 1.020 & 1.020 \\
& & $(0.020)$ & $(0.004)$ & $(0.005)$ \\
Direct transfers (euro billions) & & & & 1.009 \\
& & & & $(0.020)$ \\
Trade & & & & 1.015 \\
& 0.000 & 2.744 & 0.000 & $0.069)$ \\
Constant & $(2.138)$ & $(0.714)$ & $(1.195)$ & $(2.224)$ \\
& & & &
\end{tabular}

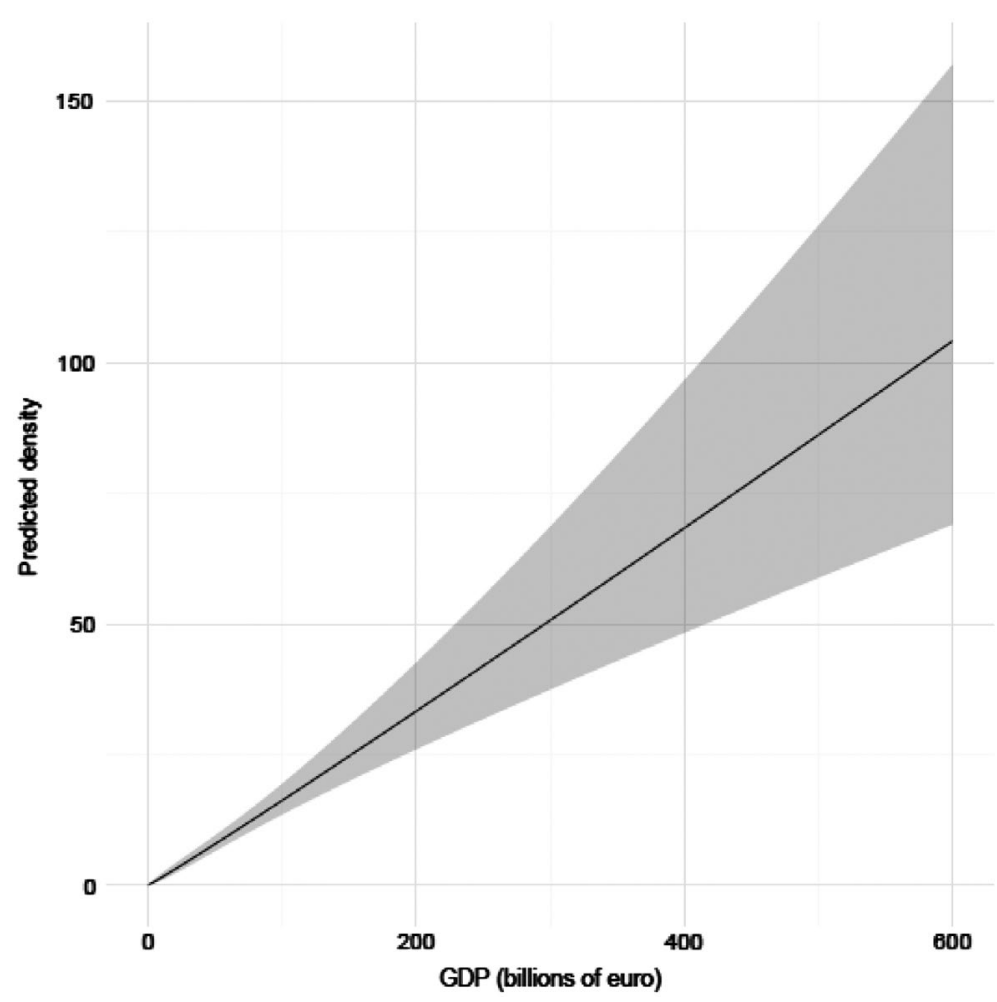

Figure 1. Plot of predicted density vs. GDP. 
pseudo- $\mathrm{R}^{2}$ is relatively high for this model (0.26), indicating that economic resources are a very strong predictor of density.

The second model is also bivariate and uses instead the variable that represents a country's cultural resources. Its effect is as hypothesised: a greater share of individuals who participate in one or more voluntary associations is associated with a higher density $(p<0.01)$. Although the variable is significant, the model fit (pseudo- $R^{2}=0.03$ ) does not reach the level observed in Model 1. In Model 3 we combine the two main variables whose effects remain significant. Note that the correlation between associational membership and the logarithm of GDP is moderate $(r=0.35)$ but the effect of both variables are significant. Finally, Model 4 introduces controls for EU direct transfers and trade dependence. Both variables are correlated with economic resources, justifying their inclusion as control variables. ${ }^{12}$ Neither of them are significant but the variables representing economic and cultural resources are robust to this specification (for both variables, $p<0.01$ ).

Table 3 allows for a more intuitive substantive interpretation of the coefficients in the negative binomial models. When the coefficient from a negative

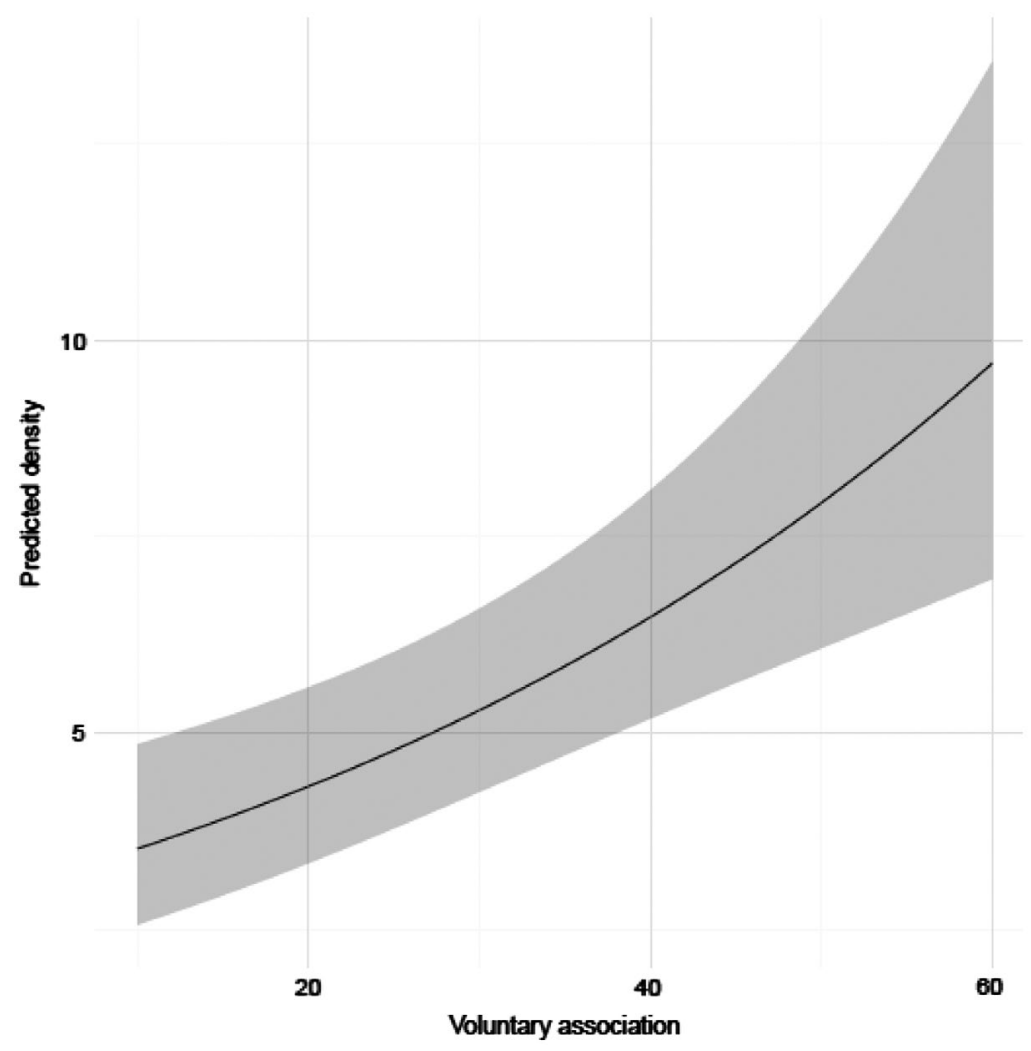

Figure 2. Plot of predicted density vs. voluntary association. 
binomial model is exponentiated, the resulting value (referred to in some contexts as the incidence rate ratio) can be interpreted as the marginal factor change in the dependent variable for a one-unit change in the independent variable. Increasing the logarithm of a country's GDP by one increases the expected density by a factor of nearly three in the three models in which that variable is present. The effect of a change in the logarithm of a country's GDP is in itself not substantively meaningful, so Figure 1 plots the expected number of organised interests for changes in raw GDP along with the 95\% confidence interval and with all other variables held constant at their means. The figures underline the substantial effect of GDP on the predicted number of groups as GDP moves within its observed range.

Considering cultural resources, according to Table 3 , a one percentage point increase in the proportion of individuals who participate in national associational life increases the expected density of groups present in the EP by a factor of 1.02 (Models 3 and 4). Figure 2 plots the expected number of organised interests for changes in this variable along with its $95 \%$ confidence interval and shows a modest increase in the predicted density across the observed range of this variable.

\section{Conclusion}

Even if interest groups are widely perceived as playing a crucial role in European governance and may represent both territorial and functional interests, existing interest group research has paid little attention to the descriptive representation of organised interests from different member states. Focusing on the case of the EP and relying on a new, unique dataset of actors registered to lobby this institution we conduct a comparative study of the density of national organised interests. We first argue that density is a relational concept and show how the density rank is affected by the benchmark employed. Countries with a high number of interest groups per MEP are among the oldest members of the EU and not necessarily the same ones as those that score highest when we examine the number of organised interests in relation to the size of the economy or the size of the population.

Second, we present a systematic explanation of the number of organised interests from different member states in the lobbying community of the EP. We focus on those factors which might affect the capacity of national organised interests to be represented in the EP lobbying community and control for factors that might affect their incentives to mobilise. In contrast to existing studies of the density of organised interests we draw specific attention to not only economic but also cultural resources.

Even if it has been argued that the EU might be a least likely case for finding strong support that supply-side factors affect density, we find strong support that not only economic but also cultural resources affect the number of 
organised interests from a country. Both the size of the national economy as well as the level of organisational engagement of the population are highly significant when it comes to explaining variation in the national number of interest groups. That the number of groups in the EP is constrained by the economic resources available in the environment in which they operate delivers strong support for the work of interest group population ecologists (e.g. Berkhout et al. 2015; Gray and Lowery 2000). We add to this work by emphasising the role which cultural resources play as a foundation for the maintenance of a strong lobbying presence at the supranational level. Citizens' associational engagement might help to overcome collective action problems of mobilising and stimulate learning processes that help organised interests to develop an effective supranational lobbying presence.

Importantly, the reason many countries do not have a strong presence of interest groups in the EP is therefore not only related to low levels of economic resources but also to the fact that they have a small engagement in organised civil society to begin with. This issue is relevant in the new Eastern and Central European member states that do not have the same tradition of civil society involvement as many older Western European member states (see also Cekik 2017). For them, a lobbying presence in Brussels is unlikely to result from increasing trade and fiscal transfers as long as their civil society engagement remains weak. Strong trade integration into the EU and fiscal transfers will still be beneficial for their economies but will not in themselves stimulate stronger involvement in EU lobbying.

There is potential to scrutinise the explanatory potential of associational engagement further in future work on interest group density when additional interest group population data are coded and when more associational engagement data from cross-national surveys on the EU member states become available. Future research should also expand our study of national differences in organised interests in the EP to other lobbying venues. Moreover, even if research at the national level of lobbying in several arenas or venues (e.g. Binderkrantz et al. 2015) leads us to expect that there is likely to be a high correlation between the number of national groups lobbying the EP and other venues, there is potential to extend our approach to other venues for EU lobbying. Examining the determinants of having a strong lobbying presence is particularly important in the European Union, which is designed in such a way that it is highly dependent on interest representatives from its different member states to secure input legitimacy.

\section{Notes}

1. http://europa.eu/legislation_summaries/institutional_affairs/treaties/lisbon_ treaty/ai0010_en.htm (accessed 20 March 2015).

2. http://www.europarl.europa.eu/sides/getDoc.do?language=EN\&type=IM-PRE SS\&reference=20070910BKG10267 (accessed 22 March 2015). 
3. http://www.europarl.europa.eu/sides/getDoc.do?pubRef=-//EP//TEXT+IM-PR ESS+20071008IPR11353+0+DOC+XML+V0//EN (accessed 22 March 2015).

4. http://ec.europa.eu/transparencyregister/public/homePage.do? redir=false\& locale=en (accessed 24 April 2015).

5. Focusing on the EP has the advantage that it enables us to look at country-level representation not only with respect to benchmarks for the size of the economy and population but also with respect to representatives from a country in the European Parliament.

6. http://ec.europa.eu/transparency/civil_society/general_overview_en.htm\#9 (accessed 22 March 2015).

7. There is disagreement on whether a higher number of groups impact on governmental performance in a positive or negative way. According to 'pluralists', a higher number of groups might help ensure a smoother transmission of public preferences to policy-makers whereas another prominent view expects a higher number of groups to increase the likelihood that policies are biased away from the interest of the median voter (for a review of this literature, see Rasmussen et al. 2014).

8. The downside to using the EP doorpass data for 2005 to 2009 is that the population data are not as up-to-date as in the Transparency Register. However, because questions about associational engagement have not been asked in recent Eurobarometer surveys, we could not relate this variable to the latest version of the Transparency data.

9. Another important reason for not exploiting the time dimension in the EP data between 2005 and 2009 is that that we do not have yearly measures of associational engagement for the period.

10. These include recreational organisations (sports or outdoor clubs); education, arts, music or cultural associations; trade unions; business or professional organisations; consumer organisations; international organisations; organisations for environmental protection or animal rights; charity or social aid organisations; leisure associations for the elderly; organisations for the defence of elderly rights; religious or church organisations; political parties or organisations; organisations defending the interests of patients and/or the disabled; and other interest groups for specific causes such as women, people with specific sexual orientations, or local issues.

11. In a related study, Messer et al. (2011) use the number of EU citizens active in groups related to a social policy area (or 'guild') to measure the potential number of constituents for groups in the area active in EU lobbying, which they expect to be positively related to actual numbers of groups. Instead we use the overall share of associational engagement to measure the cultural capital of a country. What matters to us is therefore the relative support for associations in the electorate rather than absolute number of citizens participating in groups.

12. By this token, population should also be included as a control variable, but the very high degree of correlation between population and GDP in EU countries introduces significant multicollinearity to models containing both variables. Because of the likely effect of length of EU membership on density and its moderate correlation with associational engagement, this variable might also be included as a control variable, but the low number of observations limits the possibility for additional controls. Nevertheless, the results are robust when the length of EU membership is added to the final model. 


\section{Acknowledgements}

We would like to thank Jens Blom-Hansen, Rainer Eising, Darren Halpin, Mads Dagnis Jensen, Heike Klüver and Michael Tatham for helpful comments on previous drafts of this paper. In addition, the paper received useful feedback from the participants at the workshop on Multilevel Interest Representation in the European Union at the Ruhr University of Bochum on 28-29 April 2016, the workshop on Interest Group Populations in Comparative Perspective at the University of Hamburg on 8-9 May 2015, the 2015 Annual Meeting of the Danish Political Science Association in Kolding and the 2015 Annual Conference of the European Political Science Association in Vienna. Moreover, we are grateful for the insightful and constructive comments from our two reviewers, whose feedback was helpful in revising our contribution.

\section{Disclosure statement}

No potential conflict of interest was reported by the authors.

\section{Funding}

This work was financially supported by the Netherlands Organisation for Scientific Research [grant number 461-10-519] under the European Science Foundation [grant number 10-ECRP-008] and the Danish Council for Independent Research [grant number 0602-02642B].

\section{Notes on contributors}

Brendan J. Carroll is Assistant Professor at Leiden University's Institute of Public Administration, He teaches and publishes on research design and methods, comparative public policy, regulatory implementation, EU governance and interest group advocacy/ lobbying. Recent publications have appeared in the British Journal of Political Science, European Journal of Political Research and Public Organization Review. [b.j.carroll@ fgga.leidenuniv.nl]

Anne Rasmussen is Professor in Political Science at the University of Copenhagen and affiliated to Leiden University's Institute of Public Administration. Her current research analyses decision-making, political parties, interest representation and political responsiveness. Her recent work has appeared in the British Journal of Political Science, Comparative Political Studies, European Journal of Political Research, Party Politics and Journal of European Public Policy amongst others. [ar@ifs.ku.dk]

\section{References}

ALTER-EU (2012). 'Dodgy Data: Time to Fix the EU's Transparency Register, available at http://www.Alter-Eu.Org/Sites/Default/Files/Documents/Dodgy-Data.Pdf (accessed 12 August 2012).

Andrews, Rhys (2011). 'Exploring the Impact of Community and Organizational Social Capital on Government Performance: Evidence from England', Political Research Quarterly, 64:4, 938-49. 
Bailer, Stefanie, Thilo Bodenstein, and V. Finn Heinrich (2013). 'Explaining the Strength of Civil Society: Evidence from Cross-Sectional Data', International Political Science Review, 34:3, 289-309.

Baroni, Laura (2014). 'Information Counts: Interest Group Success in the European Parliament', Salzburg Centre of European Union Studies, PhD-Dissertation.

Baroni, Laura, Brendan J. Carroll, Adam William Chalmers, Luz Maria Munoz Marquez, and Anne Rasmussen (2014). 'Defining and Classifying Interest Groups', Interest Groups \& Advocacy, 3:2, 141-59.

Berkhout, Joost, Brendan J. Carroll, Caelesta Braun, Adam W. Chalmers, Tine Destrooper, David Lowery, Simon Otjes, and Anne Rasmussen (2015). 'Interest Organizations Across Economic Sectors: Explaining Interest Group Density in the European Union', Journal of European Public Policy, 22:4, 462-80.

Beyers, Jan, Rainer Eising, and William Maloney (2008). 'Researching Interest Group Politics in Europe and Elsewhere: Much We Study, Little We Know?', West European Politics, 31:6, 1103-28.

Beyers, Jan, Laura Chaqués Bonafont, Andreas Dür, Rainer Eising, Danica Fink-Hafner, David Lowery, Christine Mahoney, William Maloney, and Daniel Naurin (2014). 'The Intereuro Project: Logic and Structure', Interest Groups \& Advocacy, 3:2, 126-40.

Binderkrantz, Anne Skorkjær, Peter Munk Christiansen, and Helene Helboe Pedersen (2015). 'Interest Group Access to the Bureaucracy, Parliament, and the Media', Governance, 28:1, 95-112.

Bischoff, Ivo (2003). 'Determinants of the Increase in the Number of Interest Groups in Western Democracies: Theoretical Considerations and Evidence from 21 OECD Countries', Public Choice, 114:1/2, 197-218.

Boix, Carles, and Daniel N. Posner (1998). 'Social Capital: Explaining Its Origins and Effects on Government Performance', British Journal of Political Science, 28:4, 686-93.

Bouwen, Pieter (2004). 'Exchanging Access Goods for Access: A Comparative Study of Business Lobbying in the European Union Institutions', European Journal of Political Research, 43:3, 337-69.

Broscheid, A., and D. Coen (2003). 'Insider and Outsider Lobbying of the European Commission an Informational Model of Forum Politics', European Union Politics, $4: 2,165-89$.

Broscheid, Andreas, and David Coen (2007). 'Lobbying Activity and Fora Creation in the EU: Empirically Exploring the Nature of the Policy Good', Journal of European Public Policy, 14:3, 346-65.

Burns, Charlotte, Anne Rasmussen, and Christine Reh (2013). 'Legislative Codecision and its Impact on the Political System of the European Union', Journal of European Public Policy, 20:7, 941-52.

Cekik, Aneta (2017). 'Adapting to Europe? Business Interests and Civil Society Groups in Accession Countries', West European Politics, doi: 10.1080/01402382.2017.1308696.

Coates, Dennis, Jac C. Heckelman, and Bonnie Wilson (2007). 'Determinants of Interest Group Formation', Public Choice, 133:3-4, 377-91.

Coen, David (1997). 'The Evolution of the Large Firm as a Political Actor in the European Union', Journal of European Public Policy, 4:1, 91-108.

Coen, David, and Alexander Katsaitis (2013). 'Chameleon Pluralism in the EU: An Empirical Study of the European Commission Interest Group Density and Diversity Across Policy Domains', Journal of European Public Policy, 20:8, 1104-19.

Coleman, James Samuel (1990). Foundations of Social Theory. Cambridge, MA: Harvard University Press. 
Corbett, Richard, Francis Jacobs, and Michael Shackleton (2007). The European Parliament. London: John Harper Publishing.

Cram, Laura (1998). 'The EU Institutions and Collective Action: Constructing a European Interest', in J. Greenwoord and M. Aspinwall (eds.), Collective Action in the European Union. Interests and the New Politics of Associability. London: Routledge, 63-80.

Cusack, Thomas R. (1999). 'Social Capital, Institutional Structures, and Democratic Performance: A Comparative Study of German Local Governments', European Journal of Political Research, 35:1, 1-34.

Delgado-Márquez, Blanca L., Michael Kaeding, and Antonio Palomares (2013). 'A More Balanced Composition of the European Parliament with Degressive Proportionality', European Union Politics, 14:3, 458-71.

Dür, Andreas, and Gemma Mateo (2012). "Who Lobbies the European Union? National Interest Groups in a Multilevel Polity', Journal of European Public Policy, 19:7, 969-87.

Eising, Rainer (2007). 'Institutional Context, Organizational Resources and Strategic Choices: Explaining Interest Group Access in the European Union', European Union Politics, 8:3, 329-62.

Eising, Rainer, Daniel Rasch, Danica Fink-Hafner, Mitja Hafner-Fink, Meta Novak and Patrycja Rozbicka (2017). 'Who Says What to Whom? Alignments and Arguments in EU Policy Making', West European Politics, doi: 10.1080/01402382.2017.1320175.

Gray, Virginia, and David Lowery (2000). The Population Ecology of Interest Representation. Ann Arbor: University of Michigan Press.

Hanegraaff, Marcel, Caelesta Braun, Dirk De Bièvre, and Jan Beyers (2015). 'The Domestic and Global Origins of Transnational Advocacy: Explaining Lobbying Presence During WTO Ministerial Conferences', Comparative Political Studies, 48:12, 1591-1621.

Hix, Simon, and Bjorn Hoyland (2011). The Political System of the European Union. London: Palgrave Macmillan.

Jackman, Robert W., and Ross A. Miller (1998). 'Social Capital and Politics', Annual Review of Political Science, 1:1, 47-73.

Knodt, Michèle (2011). 'Strategies of Territorial and Functional Interests: Towards a Model of European Interest Intermediation?', Journal of European Integration, 33:4, 419-35.

Kohler-Koch, Beate (1997). 'Organized Interests in the EC and the European Parliament', European Integration Online Papers (EIoP) Vol. 1 (1997) No 9, 1:9. http://eiop.or.at/ eiop/texte/1997-009a.htm

Lehmann, Wilhelm (2009). 'The European Parliament', in David, Coen and Jeremy Richardson (eds.), Lobbying the European Union. Institutions, Actors, and Issues. Oxford: Oxford University Press, 39-69.

Lindberg, Björn, Anne Rasmussen, and Andreas Warntjen (2008). 'Party Politics as Usual? The Role of Political Parties in EU Legislative Decision-Making', Journal of European Public Policy, 15:8, 1107-26.

Marks, Gary, and Marco Steenbergen, eds. (2004). European Integration and Political Conflict. Oxford: Oxford University Press.

Marks, Gary, Francois Nielsen, Leonard Ray, and Jane E. Salk (1996). 'Competencies, Cracks, and Conflicts: Regional Mobilization in the European Union', Comparative Political Studies, 29:2, 164-92.

Marsh, Michael, and Bernhard Wessels (1997). 'Territorial Representation', European Journal of Political Research, 32:2, 227-41.

Marshall, David (2010). 'Who to Lobby and when: Institutional Determinants of Interest Group Strategies in European Parliament Committees', European Union Politics, 11:4, 553-75. 
Marshall, David (2015). 'Explaining Interest Group Interactions with Party Group Members in the European Parliament: Dominant Party Groups and Coalition Formation', Journal of Common Market Studies, 53:2, 311-29.

Messer, Anne, Joost Berkhout, and David Lowery (2011). 'The Density of the EU Interest System: A Test of the ESA Model', British Journal of Political Science, 41:1, 161-90.

Norris, Pippa (2003). Democratic Phoenix: Reinventing Political Activism. Cambridge: Cambridge University Press.

Pitkin, Hanna (1967). The Concept of Representation. Berkeley: University of California Press.

Putnam, Robert D. (1993). Making Democracy Work. Civic Traditions in Modern Italy. Princeton, NJ: Princeton University Press.

Putnam, Robert D. (1995). 'Tuning in, Tuning Out: The Strange Disappearance of Social Capital in America', Political Science and Politics, 28:4, 1-20.

Putnam, Robert D. (2000). Bowling Alone: The Collapse and Revival of American Community. NewYork, NY: Simon \& Schuster.

Rasmussen, Maja Kluger (2015). 'The Battle for Influence: The Politics of Business Lobbying in the European Parliament', Journal of Common Market Studies, 53:2, 365-82.

Rasmussen, Anne, and Petya Alexandrova (2012). 'Foreign Interests Lobbying Brussels: Participation of Non-EU Members in Commission Consultations', Journal of Common Market Studies, 50:4, 614-31.

Rasmussen, Anne, and Brendan Carroll (2014). 'Determinants of Upper-Class Dominance in the Heavenly Chorus: Lessons from European Commission Online Consultations', British Journal of Political Science, 44:2, 445-59.

Rasmussen, Anne, and Vlad Gross (2015). 'Biased Access? Exploring Selection to Advisory Committees', European Political Science Review, 7:3, 343-72.

Rasmussen, Anne, Brendan Carroll, and David Lowery (2014). 'Representatives of the Public? Public Opinion and Interest Group Activity', European Journal of Political Research, 53:2, 250-68.

Richardson, Jeremy, and Sonia Mazey (2015). 'Shooting Where the Ducks Are: EU Lobbying and Institutionalized Promiscuity', in Jeremy, Richardson and Sonia Mazey (eds.), European Union. Power and Policymaking. London: Routledge, 419-40.

Schattschneider, Elmer E. (1960). The Semisovereign People. New York, NY: Holt, Rinehart, and Winston.

Schlozman, Kay Lehman (1984). 'What Accent the Heavenly Chorus? Political Equality and the American Pressure System', The Journal of Politics, 46:4, 1006-32.

Schlozman, Kay Lehman, and John T. Tierney (1986). Organized Interests and American Democracy. New York, NY: Harper and Row.

Tatham, Michaël (2017). 'Networkers, Fund-Hunters, Intermediaries, or Policy Players? The Activities of Regions in Brussels', West European Politics, doi: 10.1080/01402382.2017.1303246.

Tavits, Margit (2006). 'Making Democracy Work More? Exploring the Linkage between Social Capital and Government Performance', Political Research Quarterly, 59:2, 211-25.

Wessels, Bernhard (1999). 'European Parliament and Interest Groups', in Richard S. Katz and Bernhard Wessels (eds.), The European Parliament, National Parliaments, and European Integration. Oxford: Oxford University Press, 105-28.

Wonka, Arndt, Frank R. Baumgartner, Christine Mahoney, and Joost Berkhout (2010). 'Measuring the Size and Scope of the EU Interest Group Population', European Union Politics, 11:3, 463-76. 